M A Woods

\title{
UK Chalk Group stratigraphy (Cenomanian - Santonian) determined from borehole geophysical logs
}

\author{
M. A. Woods \\ British Geological Survey, Keyworth, Nottingham, NG12 5GG, England \\ (e-mail: MAW@BGS.ac.uk)
}

\begin{abstract}
Borehole geophysical logs through the Chalk Group of south-east England have distinctive profiles that correspond with formational boundaries, recognised by lithological changes in borehole core and mapped by the British Geological Survey on the basis of lithology and topographic features at outcrop. Borehole geophysics graphically demonstrates the validity of the stratigraphy of the Chalk Group used by the British Geological Survey, and can be used to refute recent arguments against lithostratigraphical subdivision of the White Chalk Subgroup. Although intraformational changes in the detail of borehole geophysical logs may occur between regions, generalised trends can still be used for inter-regional recognition of formations in the subsurface. Much previous work has focused on the utility of borehole geophysics for marker-bed recognition and correlation in the Chalk Group, but little attention has been paid to the more fundamental task of characterising formations. This approach allows a much greater appreciation of regional Chalk Group stratigraphy than might be evident from available outcrops, and is the first step in the development of three-dimensional digital geological models of the Chalk Group.
\end{abstract}

Key Words: Chalk Group, geophysical logs, stratigraphy 


\section{Introduction}

At a recent conference of the Engineering Group of the Geological Society (University of Reading, 20th April 2004) some delegates were critical of the Chalk Group lithostratigraphy used by the British Geological Survey (BGS). It was argued that there was no fundamental basis for many of the stratigraphical subdivisions of the Chalk Group shown on recent BGS maps, and that the traditional tripartite (Lower, Middle \& Upper Chalk) classification, based on the recognition of two indurated chalk horizons (the Melbourn Rock and Chalk Rock), was preferable. Field evidence in support of the BGS methodology was demonstrated in a presentation by D. T. Aldiss (BGS).

This paper shows that borehole geophysical logs can be used in the subsurface recognition and correlation of formations in the Chalk Group mapped by the BGS, and strongly supports the retention of this stratigraphy rather than its abandonment in favour of the traditional scheme. The log signatures provide graphic evidence of the primary lithological variation that some critics have disputed to exist, particularly in the White Chalk Subgroup.

During the last 20 years there has been renewed interest in the stratigraphy of the Chalk Group, especially following the publication of new classifications for the Chalk Group of Sussex (Mortimore, 1986) and Kent (Robinson, 1986). This work has been driven by the need of the user community (predominantly civil engineers) for a geological classification that more accurately reflects large-scale changes in the 


\section{A Woods}

physical characteristics and engineering behaviour of chalk. A plethora of named marker beds, cyclostratigraphical units, members and formations has arisen as a result of detailed work in different regions of the UK (Wood \& Smith, 1978; Bailey et al., 1983; Bromley \& Gale, 1982; Jarvis \& Woodroof, 1984; Jarvis \& Tocher, 1987; Gale, 1995, 1996; Whitham, 1991, 1993; Bristow et al., 1995, 1997, 1999 ; Wood, 1988; Mortimore et al., 2001). A significant rationalisation of stratigraphical nomenclature was achieved at a meeting of the Stratigraphy Commission of the Geological Society, convened in November 1999 at the headquarters of the BGS at Keyworth, Nottingham. Following discussions by all interested parties, a broadly agreed stratigraphical framework was decided upon for successions in northern and southern England (Rawson et al., 2001; Fig 1), and this is the basis for current BGS work on the Chalk Group.

Realisation that borehole geophysical logs could be used to identify and correlate subsurface Chalk Group successions predates the recent work on the Group's stratigraphy. Gray $(1958,1965)$ identified marker-bands on resistivity logs of the BGS Leatherhead (Fetcham Mill) Borehole, Surrey [TQ 1581 5650], and these were used by Murray (1986) as a basis for correlating Cenomanian and Turonian successions from the London Basin to east Yorkshire. Barker et al. (1984) showed the relationship between lithostratigraphy and borehole geophysical logs in the Chalk Group of Lincolnshire and Humberside, and Mortimore (1986) and Mortimore \& Pomerol (1987) focused on the utility of borehole geophysics for tracing marker beds in the Chalk Group across the Anglo-Paris Basin. Unfortunately, many of these advances were too late for incorporation in the Geological Society's Special Report on Geophysical logs in British Stratigraphy (Whittaker et al., 1985), which uses the 


\section{A Woods}

traditional tripartite (Lower, Middle, Upper) subdivision of the Chalk Group, and does not illustrate any resistivity log interpretations for this interval. Nevertheless, Whitaker et al. (1985) remains a fundamental introductory reference to the theory and practice of geophysical log interpretation in UK stratigraphy.

With such a wealth of data already published, the BGS realised that its archives of geophysical log data could provide useful regional overviews of the subsurface Chalk Group stratigraphy, and allow the development of three-dimensional digital stratigraphical models. Since 1995, the BGS has used geophysical logs to research the subsurface Chalk Group successions across southern England, including London, Kent, Berkshire, Hertfordshire, Wiltshire, Dorset and parts of East Anglia (Fig. 2). As well as being a valuable tool in support of mapping, the identification of the BGS Chalk Group stratigraphy on geophysical logs from water-supply boreholes has greatly benefited hydrogeological projects, providing insights into the relationship between subsurface water flows and lithostratigraphy (Jones \& Robbins, 1999; Buckley et al., 2001; Schürch \& Buckley, 2002). Significantly, the BGS work has focused on the geophysical log characterisation of formations within the Chalk Group, as well as on marker-bed identifications. This approach builds on the work of Bristow et al. (1997, fig. 9), who illustrated the formational geophysical log correlation of part of the Chalk Group across Dorset, Hampshire and Sussex. In many cases the correlation of marker-beds can be problematic where geophysical logs are of poor resolution. This is particularly true of many older-style borehole logs based on single point resistivity measurements at incremental depths, but even these are interpretable in the broader framework of formational stratigraphy. The details of resistivity log types shown on Figs 3-8 are given in Appendix 1. 


\section{Stratigraphy}

The results of the BGS work show that for Cenomanian to Santonian Chalk Group successions, there are gross changes in borehole gamma and resistivity log signatures that can be matched with formational boundaries in borehole core and at outcrop. These features are described below with reference to the standard Cenomanian to Santonian Chalk Group stratigraphy for south-east England (Fig. 1). The geophysical log characterisation of post-Santonian Chalk Group formations is still being developed . Bristow et al. (1997, fig. 8) illustrated consistent borehole geophysical log trends in Late Santonian and Early Campanian successions in parts of Hampshire and Sussex, but lack of cored and geophysically logged boreholes through higher parts of the Chalk Group means that interpretations for younger intervals are still too reliant on tentative extrapolations of outcrop thicknesses.

\section{West Melbury Marly Chalk Formation}

The base of the West Melbury Marly Chalk Formation is the base of the Chalk Group, marked by the unconformable contact with the underlying Gault or Upper Greensand formations. Where Gault underlies the Chalk, the basal Chalk Group is generally marked by a relative drop in gamma log values, and sometimes by a small resistivity log spike, the latter representing the sandy and silty Glauconitic Marl Member at the base of the West Melbury Marly Chalk Formation. Where Upper Greensand underlies the Chalk Group, then the most conspicuous change is usually seen on resistivity logs, 


\section{A Woods}

with a fall in values in the basal Chalk Group (e.g. Leatherhead Borehole, Fig. 3) reflecting the presence of marl-rich chalk.

The West Melbury Marly Chalk shows a general upward increase in resistivity and decline in the gamma log profile (Fig. 4). This pattern reflects the upward reduction in the amount of mudstone, usually present as rhythmic alternations ('marls') with limestones. Some of the limestones are strongly indurated and stand out as sharp spikes on the resistivity log, producing a very serrated signature.

\section{Zig Zag Chalk Formation}

The Zig Zag Chalk Formation is characterised by higher resistivity than the underlying West Melbury Marly Chalk Formation. On some resistivity logs the overall profile through the Zig Zag Chalk appears relatively flat, in others there is an upward increase in resistivity, but a much less pronounced change than that seen through the West Melbury Marly Chalk. The key to the geophysical interpretation of the base of the Zig Zag Chalk is identification of the Cast Bed, the basal markerhorizon. Woods \& Aldiss (2004) showed that this horizon is often present as a small, but distinct and laterally persistent spike on resistivity logs. Using lithological, macrofossil and microfossil data from a cored borehole to identify the Cast Bed on a related resistivity log is the most accurate method for interpreting the logs of uncored boreholes. This is demonstrated by the Netheravon Borehole [SU 1690 4830] in Wiltshire, the North Farm Borehole [SU 3321 7971] in Berkshire, and the Aycliff Borehole in Kent, in which the lithology and macrofossil data from the core clearly reveal the identity of the Cast Bed spike on the resistivity signature (Figs 3, 4 \& 5). In 


\section{A Woods}

the Berkshire Downs, continuous resistivity logs show a distinctive and consistent pattern of inflections in the c. 8 m thick interval above the Cast Bed that is helpful to the interpretation of uncored successions (Fig. 4). A somewhat expanded version of the same inflection pattern can be seen in the interval above the Cast Bed on the resistivity log of the Fonthill Bishop Borehole in Wiltshire (Fig. 4). In some regions there are persistent trends in the resistivity pattern of the Zig Zag Chalk that are of value for detailed correlation (e.g. Berkshire Downs; Fig. 4). There is an upward trend of declining gamma log values through the Zig Zag Chalk, continuing the trend seen in the underlying West Melbury Marly Chalk.

\section{Holywell Nodular Chalk Formation}

With the exception of the basal unit (Plenus Marls Member), the Holywell Nodular Chalk is characterised by much higher resistivity log values than adjacent formations, and is usually one of the easiest stratigraphical intervals to identify. The mudstonerich Plenus Marls, at the base of the formation, are marked by a dramatic fall in the resistivity log values, followed immediately by a sharp increase associated with the highly indurated lithology of the Melbourn Rock (Figs 3, 5 to 8). Since the combined thickness of the Plenus Marls and Melbourn Rock is typically just a few metres, these resistivity changes are usually manifest as very sharp inflections on log signatures. Gamma logs typically show a sharp high value spike in the clay-rich Plenus Marls, followed by a significant fall in values above. On high resolution resistivity logs, the low resistivity inflection formed by the Plenus Marls sometimes has a small spike within it, probably representing the less clay-rich and more indurated central part of 


\section{A Woods}

the Plenus Marls, equating with Bed 3 of Jefferies (1963) detailed Plenus Marls stratigraphy.

The high resistivity interval formed by the Holywell Nodular Chalk is punctuated by thin, sharply defined, low resistivity horizons, representing the thin marls that are commonly developed through the formation. In some regions, the form of the resistivity signature through the Holywell Nodular Chalk can be broken down into three broad high resistivity spikes that appear to be widely developed and of value for correlation (e.g. Netheravon Borehole, Fig. 4; Berkshire Downs, Fig. 7). The lowest of these spikes is usually the Melbourn Rock; influxes of shell-rich chalk appear to form the two higher spikes in the Berkshire Downs.

\section{New Pit Chalk Formation}

On borehole resistivity logs, the New Pit Chalk is represented by a broad interval of lowered resistivity log values between the higher values characterising the Holywell Nodular Chalk (below) and the Lewes Nodular Chalk (above) (Figs. 3, 6 to 8). In the Netheravon Borehole (Fig. 3) and parts of the Berkshire Downs (Fig. 7), the New Pit Chalk appears thin because of erosion and/or non-deposition associated with a regionally developed hardground (Ogbourne Hardground) at the base of the immediately overlying Lewes Nodular Chalk (Gale, 1996; Woods \& Aldiss, 2004). The base of the New Pit Chalk is within the interval of sharply declining resistivity log values that marks the upward transition from relatively hard Holywell Nodular Chalk to softer New Pit Chalk Formation. By reference to a cored and geophysically logged borehole, the base of the New Pit Chalk can successfully be traced out on the 


\section{A Woods}

geophysical logs of uncored boreholes. Often the boundary is coincident with a small but prominent spike in the gamma log (e.g. Reculver Borehole, Fig. 6), representing the Gun Gardens Main Marl of Mortimore (1986) (= Lulworth Marl of Gale, 1996), the lithological marker-bed for the junction of the Holywell Nodular Chalk and New Pit Chalk.

Resistivity logs through the New Pit Chalk generally show several consistently developed markers that are of value for correlation. These markers are low resistivity inflections, representing major marl seams in the succession that correspond with significant spikes on the gamma log. Some of these markers were identified in the Leatherhead Borehole by R. N. Mortimore, C. J. Wood and K. Murray as the New Pit Marl 1, New Pit Marl 2 and the Glynde Marl Complex (Wood,1986; Fig. 3). The New Pit Marls form a conspicuous pair of low resistivity spikes near the top of the formation, and a broad low resistivity 'embayment' (often with small parasitic spikes) is the characteristic signature of the Glynde Marl Complex at the top of the New Pit Chalk Formation. In the London, Berkshire Downs and Hertfordshire chalk successions, there are consistently developed sets of inflections that allow detailed correlation of geophysical logs in the New Pit Chalk (Figs 3, 7 \& 8). In the Berkshire Downs, a conspicuous pair of inflections in the New Pit Chalk ('Marker Marls' of Fig. 7) appear to equate with marl seams below the New Pit Marls (Woods \& Aldiss, 2004), possibly including the Round Down Marl of Gale (1996) (= Malling Street Marl of Mortimore, 1986). 


\section{A Woods}

\section{Lewes Nodular Chalk Formation}

The Lewes Nodular Chalk Formation is characterised by higher resistivity values than the underlying New Pit Chalk. However, regional stratigraphical variation at the base of the Lewes Nodular Chalk produces regional change in the response of resistivity logs through this interval. In some areas (e.g. Berkshire Downs, Chilterns), the base of the Lewes Nodular Chalk is a hardground complex (traditionally named the 'Chalk Rock') associated with the erosion and /or condensation of stratigraphical intervals (Fig. 1). More complete successions occur elsewhere (e.g. North Downs; Fig. 3), where the Chalk Rock is absent or only weakly developed.

Irrespective of whether or not the Chalk Rock is present, the incoming of hard, nodular chalk at the base of the Lewes Nodular Chalk Formation is signalled by a change in the resistivity log profile. Where no Chalk Rock is present, the generalised profile is from upwardly declining resistivity in the New Pit Chalk to gradually upwardly increasing resistivity. In some boreholes, the basal part of the Lewes Nodular Chalk appears to have a rather flat resistivity profile (e.g. Leatherhead Borehole, Fig. 3), but containing spikes of greater resistivity than occur in the top of the New Pit Chalk. A series of sharply defined low resistivity spikes, representing major marl seams in the base of the Lewes Nodular Chalk, punctuate the general trend in resistivity and are of great value for correlation (Fig. 3). These are the Southerham, Caburn and Bridgewick Marls of Mortimore (1986); the inflection in the resistivity log profile that marks the base of the Lewes Nodular Chalk usually occurs at a small resistivity high, immediately below the prominent low resistivity inflection that represents Southerham Marl 1 of Mortimore (1986) (Figs 3, 6 to 8). 


\section{A Woods}

Where the Chalk Rock is well developed, a sharp high resistivity spike marks the base of the Lewes Nodular Chalk, corresponding with the massive, indurated beds of chalk that constitute the Chalk Rock. Concentrations of glauconite and phosphate at the constituent hardground surfaces usually means that the Chalk Rock appears as a broad spike on gamma logs. On detailed resistivity logs, the component hardgrounds of the Chalk Rock may be resolvable, and in some areas at least one strong low resistivity spike (in many cases corresponding to Southerham Marl 1) occurs within the broader high resistivity spike formed by the Chalk Rock (Fig. 5).

Above the basal part of the Lewes Nodular Chalk, the form of the resistivity signature through the remainder of the formation can be quite variable, although at least two persistent types of pattern are recognisable. The first is where the resistivity signature has one or two major high resistivity spikes, separated by lower resistivity intervals (Fig. 8). Alternatively, the rise in resistivity seen at the base of the Lewes Nodular Chalk may be followed by a gradual upward decline, sometimes with a spike just below the top of the formation (Fig. 7). The high resistivity spikes represent hardgrounds or major flint-bearing intervals in the Lewes Nodular Chalk. Broad intervals of lower resistivity represent less strongly indurated beds of nodular chalk. Although marls occur in the middle and higher parts of the Lewes Nodular Chalk, few, with the local exception of the Lewes Marl and Shoreham Marl 2 (Table 1, Fig. 3, Fig. 5), are consistently resolvable on resistivity and gamma logs. 


\section{A Woods}

\section{Seaford Chalk Formation}

A variety of resistivity log patterns mark the boundary of the Lewes and Seaford Chalk formations, but at least two patterns are discernible. In some cases there is a sharp change from the hard, nodular lithology of the Lewes Nodular Chalk to the softer Seaford Chalk Formation, marked by a conspicuous decline in resistivity log values. This is shown by some boreholes in the London region (Fig. 3). In the Berkshire Downs the lithological change is more gradational, and the boundary is marked by an inflection of the resistivity log profile, below which resistivity values progressively increase in the upper part of the Lewes Nodular Chalk, and above which resistivity values remain relatively stable in the basal part of the Seaford Chalk (Fig. 7). The lower part of the Seaford Chalk Formation typically contains common semitabular flints, up to 0.3 m thick, which may be represented as a series of sharp, high resistivity spikes (e.g. Chapel Wood Borehole, Fig. 7) and make interpretation of the formational base more problematic. In some cases, a small pair of low resistivity inflections, with corresponding spikes on the gamma log, occurs at the top of the Lewes Nodular Chalk (e.g. Leatherhead Borehole, Fig. 3); they represent the Shoreham Marls of Mortimore (1986), the upper of which (Shoreham Marl 2) is the marker bed for the base of the Seaford Chalk Formation.

The lower third of the Seaford Chalk contains the Belle Tout Marls, usually discernible on good quality borehole geophysical logs (Mortimore \& Pomerol, 1987, fig. 3), but sometimes masked by the strong responses produced by flint bands. Consistent resistivity log patterns are hard to determine in the remainder of the 
M A Woods

Seaford Chalk, and the consistent characterisation of marker-beds has not been convincingly demonstrated.

\section{Newhaven Chalk Formation}

In some parts of southern England the base of the Newhaven Chalk can be recognised by a conspicuous decline in resistivity log values. This is best exemplified by the single point resistivity logs of the Leatherhead Borehole (Fig. 3) and the Shalbourne Borehole (Fig. 7), and reflects the upward appearance of very soft, poorly flinty chalk in the lower part of the Newhaven Chalk Formation.

\section{Case studies}

In order to demonstrate the consistency of borehole geophysical log response to Chalk Group lithostratigraphy, selections of borehole resistivity and gamma logs are illustrated and described from four regions of southern England: London, Kent, Berkshire Downs and Hertfordshire (Figs 2, 3, 6 to 8).

\section{London area (Fig. 3)}

The two cored and geophysically logged boreholes at Leatherhead and Warlingham provide the best means of interpreting the numerous borehole resistivity logs that traverse the Chalk in the London area. Both Leatherhead and Warlingham contain an abnormally condensed West Melbury Marly Chalk Formation (Wood, 1996), between 10 and 15 m thick, overlain by a much thicker interval (c. 50 m) of Zig Zag Chalk 


\section{A Woods}

Formation. The base of the Zig Zag Chalk is a very conspicuous high resistivity spike, referred to as the Totternhoe Stone by Murray (1986) but perhaps more correctly regarded as the Cast Bed. The Totternhoe Stone is an erosive horizon that in some areas replaces the Cast Bed as the basal marker of the Zig Zag Chalk, but it is weakly developed in the North Downs (Wood, 1996).

The Holywell Nodular Chalk is a consistently developed interval across the region, 15 to 20 m thick. The base and top of the overlying New Pit Chalk are also well defined in the London area, but the correlation of the internal stratigraphy is more problematic. A pair of low resistivity inflections, identified as New Pit Marl 1 and New Pit Marl 2 by Wood (1986) in the Leatherhead Borehole, and herein designated 'A' and 'B' in the Winchester House Borehole (Fig. 3), appear to be correlative and traceable across the region. However, upon detailed comparison of the Leatherhead and Winchester House resistivity logs, the interpretation is less straightforward; New Pit Marl 1 is probably the upper ('A') of the two inflections in the Winchester House Borehole (Fig. 3), and inflection 'B' is more likely to equate with a level below the New Pit Marls. It is also clear from the correlation that there is expansion of the New Pit Chalk in the Cheam Borehole, close to a region of inferred Mesozoic synsedimentary growth faulting (Ellison et al., 2004, fig. 42).

The Lewes Nodular Chalk, and in particular a group of marls identified in the Leatherhead Borehole as the Southerham Marl, Caburn Marl , Bridgewick Marls and Lewes Marl, is clearly traceable across the region. A high resistivity interval, just below the Lewes Marl, equates with hard, nodular chalks that elsewhere form part of the 'Chalk Rock'. Comparison of the single point and continuous resistivity logs of the 


\section{A Woods}

Leatherhead Borehole shows that two or more closely spaced marls can be represented by a single low resistivity spike, and this needs to be borne in mind when attempting detailed marker-bed correlations.

The junction of the Lewes Nodular Chalk and Seaford Chalk formations shown on Figure 3 is modified from that shown in recently published resistivity log correlations of the London area (Ellison et al., 2004, fig. 6). The additional resistivity logs shown on Figure 3, particularly that at Dagenham, demonstrate that the upper part of the Lewes Nodular Chalk is not so greatly condensed in the Grays and Winchester House boreholes as suggested by Ellison et al. (2004), although condensation of the lower part of the formation is still evident in the Grays, Dagenham and Heath Farm successions. The revised boundary is nevertheless coincident with a significant fall in resistivity, and with a significant low resistivity spike in the Heath Farm Borehole that perhaps represents Shoreham Marl 2. Outcrop data shows that there is considerable lateral variation in the thickness of the Seaford Chalk in the London area that cannot simply be explained by differential erosion at the Palaeogene contact. For example, in the Leatherhead Borehole, the total thickness of the formation is c. $40 \mathrm{~m}$, which is low compared to incomplete thicknesses derived from composite outcrop sections elsewhere in the London region (e.g. Ellison et al., 2004, fig. 8), and much less than for successions in the Berkshire Downs (Fig. 7; Woods \& Aldiss, 2004).

In the Leatherhead Borehole, the top of the Seaford Chalk and basal Newhaven Chalk are unequivocally proved by the presence of the Clandon Hardground (Wood, 1996) overlain by records of the index crinoid Uintacrinus socialis. The Newhaven Chalk Formation is the youngest part of the Chalk Group known in the London area. 
M A Woods

\section{Kent (Fig. 6)}

Many of the borehole resistivity logs from Kent reproduce features already described in the London area. Interpretation of the Grey Chalk Subgroup is based on correlations shown on Figure 4 and discussed above. The remainder of the interpretation is based on core from the Lower Venson Farm Borehole. The resistivity $\log$ of the Lewes Nodular Chalk in the Reculver 1 Borehole is abnormal; the lower than expected resistivity values probably result from the influence of saline ground water at this coastal site. Nevertheless, the gamma log of the Reculver Borehole clearly shows a series of high gamma spikes that correspond to the marl seam succession seen in the lower part of the Lewes Nodular Chalk in the London area. The lowest and most conspicuous of these gamma spikes almost certainly represents Southerham Marl 1.

In the Lower Venson Farm Borehole, the top of the Lewes Nodular Chalk is placed at a small low resistivity inflection. Although this is a short distance above the lowest microfossil evidence for the M. coranguinum Zone (Wilkinson, 2003; Fig. 6; the base of which is usually coincident with Shoreham Marl 2 and the base of the Seaford Chalk Formation) in the borehole, it accords better with lithological and macrofossil evidence from the core. A similar inflection is presumed to mark the base of the Seaford Chalk in the Reculver Borehole, and a more general fall in resistivity log values, as elsewhere, marks the base of the formation in the Motney Hill and Oare Creek boreholes. A sharp increase in the gamma log, near the top of the Reculver Borehole, represents argillaceous strata that overlie the Chalk Group. 


\section{A Woods}

Several of the boreholes shown on Figure 6 were also interpreted by Mortimore and Pomerol (1987, fig. 7), and their correlations broadly agree with the interpretation shown on Figure 6. These authors show that the series of sharp low resistivity inflections above the Southerham Marl 1 in the Oare Creek Borehole represent the Caburn Marl, Bridgewick Marls and Lewes Marl, and the Glynde Marls form the broad low resistivity inflection seen in the top of the New Pit Chalk in the Oare Creek, Boughton and St. Margarets boreholes (Fig. 6). However, a key difference exists in the interpretation of the lower part of the Boughton Borehole, which Mortimore \& Pomerol (1987) show as condensed and in part use as evidence for a region of sedimentary thinning named the 'Margate Axis'. The National Grid Reference of Mortimore \& Pomerol's Boughton log was not published, but the log has been digitised and compared with the log for Boughton shown on Figure 6. The comparison shows that they are probably logs of the same borehole; individual inflections can be matched at similar depths between the logs, but the bottom of the Mortimore \& Pomerol log falls short of the distinct high resistivity interval formed by the Holywell Nodular Chalk Formation on the Boughton log of Figure 6. This interpretation is further confirmed by a nearby borehole at Boughton Street [TR 0529 5942], showing that there is no unusual condensation of the Holywell and New Pit Chalk formations.

\section{Berkshire Downs (Fig. 7)}

Data from the Berkshire Downs has already been discussed in detail by Woods and Aldiss (2004). A selection of the logs are reproduced herein to demonstrate the 


\section{A Woods}

general continuity with the resistivity signatures already described in London and Kent, and to show their value in determining lateral changes in formational thicknesses (highlighted by grey shading on Fig. 7). A pair of low resistivity markers in the New Pit Chalk ('Marker Marls') are analagous to the two prominent low resistivity markers in the New Pit Chalk of the London area ('A' and 'B' on Figure 3), but are probably older (Woods \& Aldiss, 2004, fig. 5). The Berkshire Downs region also shows the development of the Chalk Rock. Consequently the junction of the New Pit Chalk and Lewes Nodular Chalk is more conspicuously marked on resistivity logs than in the London and Kent regions, and some marls from this interval in the London and Kent regions are absent in the Berkshire Downs. Data from the cored BGS Banterwick Barn Borehole suggests that the base of the Seaford Chalk, as marked by lithological change in the core and corresponding change in the pattern of the resistivity log, is at least locally below Shoreham Marl 2, the usual marker-bed for the base of the formation (Woods \& Aldiss, 2004).

\section{Hertfordshire (Fig. 8)}

A superb series of resistivity logs from the Chalk of Hertfordshire clearly delimits the Holywell, New Pit, Lewes and Seaford Chalk formations in the subsurface. In particular there is a very consistent development of a pair of low resistivity spikes in the New Pit Chalk, which undoubtedly represent marls, possibly correlative with the 'Marker Marls' of the Berkshire Downs area (see above). Southerham Marl 1 is conspicuously developed just above the base of the Lewes Nodular Chalk, and there are two very strong resistivity spikes in the overlying succession, representing the 'Chalk Rock' and 'Top Rock' (Fig. 1). Unfortunately, there is no nearby cored and 


\section{A Woods}

geophysically logged succession against which to confirm the geological interpretation, but it is strongly supported by the published interpretation of the Thundridge Borehole (Wood, 1986) and the interpretation of geophysical logs in the Chalk of the Hitchin district (Hopson et al., 1996, fig. 8). Further afield, the resistivity log of the cored Stowlangtoft Borehole, in the Bury St Edmunds district (Bristow, 1990; Fig. 2), strongly suggests the northward extent of the Holywell, New Pit and Lewes Nodular Chalk into southern East Anglia.

\section{Conclusions}

For Cenomanian - Santonian Chalk Group successions, borehole geophysical logs provide graphic supporting evidence for the validity of formational subdivisions mapped by the BGS. Cored and geophysically logged boreholes can be used to predict reliably the subsurface development of these formations in resistivity and gamma logs from uncored successions. These data may also reveal lateral changes in stratigraphical units that might not otherwise be seen or predicted. However, geophysical logs alone are not always reliable for marker-bed correlations, as exemplified by the New Pit Marls of the London area (Fig. 3).

Acknowledgements: I thank Vin Robinson and Alan Waters of the Environment Agency (Thames Region) for generously allowing access to their borehole records. I also thank Mid Kent Water Ltd for allowing publication of resistivity logs for the Reculver and Boughton boreholes. D. K. Buckley (BGS, Wallingford) has provided invaluable technical advice about geophysical logs and supplied digital log data. P. M. 
M A Woods

Hopson and S. G. Molyneux are also thanked for their comments on earlier drafts of this manuscript. This paper is published by permission of the Director, British Geological Survey (NERC).

\section{Appendix 1: Resistivity log types for boreholes shown in Figs 3-8}

10 inch normal resistivity:

Warlingham

16 inch normal reistivity:

Oare Creek (Faversham); Boughton Pumping Station; Lower Venson Farm;

Bh 2; St. Margarets At Cliffe C1 Seaview; Fetcham Mill (Leatherhead);

Fonthill Bishop; North Farm; South Fawley; The Barracks OBH; Worlds

Wonder OBH; Horsehall Hill; Shalbourne Experimental; Winterbourne OBH

(cored); Chapel Wood; Brightwalton Holt; Thundridge; ?Motney Hill;

?Challenge Farm; Dagenham

64 inch single point resistivity:

Heath Farm; Grays

5 foot single point resistivity:

Jewels Wood; Luddesdown; Plumstead Pumping Station; Winchester House;

Netheravon; Aycliff (Dover No. 1); Rothampstead Experimental Farm;

Hatfield Aerodrome; British Railways Hatfield; Sacombe Pound, Broadmeade

(Ware); Hoddesdon

5 foot 6 inch single point resistivity:

Selling (Featherbed Lane)

7 foot 6 inch single point resistivity:

Welwyn (Fulling Mill Lane) 
M A Woods

$0.5 \mathrm{~m}$ single point resistivity:

Woodcote

$2 \mathrm{~m}$ single point resistivity:

Hyde Mill Harpenden

3 m single point resistivity:

Cheam

Induction resistivity:

Reculver 1; Banterwick Barn No. 2

\section{References}

BAILEY, H. W., GALE, A. S., MORTIMORE, R. N., SWIECICKI, A. \& WOOD, C. J. 1983. The Coniacian-Maastrichtian stages of the United Kingdom, with particular reference to southern England. Newsletters on Stratigraphy, 12, 29-42.

BARKER, R. D., LLOYD, J. W. \& PEACH, D. W. 1984. The use of resistivity and gamma logging in lithostratigraphical studies of the Chalk in Lincolnshire and South Humberside. Quarterly Journal of Engineering Geology, 17, 71-80.

BRISTOW, C. R. 1990. Geology of the country around Bury St Edmunds, Memoir of the British Geological Survey, Sheet 189 (England \& Wales).

BRISTOW, C. R., BARTON, C. M., FRESHNEY, E. C., WOOD, C. J., EVANS, D. J., COX, B. M., IVIMEY-COOK, H. \& TAYLOR, R. T. 1995. Geology of the 
M A Woods

country around Shaftesbury. Memoir of the British Geological Survey, Sheet 313 (England \& Wales)

BRISTOW, C. R., BARTON, C. M., WESTHEAD, R. K., FRESHNEY, E. C., COX, B. M. \& WOODS, M. A. 1999. The Wincanton District - a concise account of the geology. Memoir of the British Geological Survey, Sheet 297 (England \& Wales).

BRISTOW, C. R., MORTIMORE, R. N. \& WOOD, C. J. 1997. Lithostratigraphy for mapping the Chalk of southern England. Proceedings of the Geologists' Association, 108, 293-315.

BROMLEY, R. G. \& GALE, A. S. 1982. The lithostratigraphy of the English Chalk Rock. Cretaceous Research, 3, 273 - 306.

BUCKLEY, D. K., HINSBY, K. \& MANZANO, M. 2001. Application of geophysical logging techniques to examine coastal aquifer palaeohydrogeology. In: EDMUNDS, W. M. \& MILNE, C. J. (eds). Palaeowater in Coastal Europe, evolution of groundwater since the late Pleistocene. Geological Society Special Publication No. 189, 251-270.

ELLISON, R. A., WOODS, M. A., ALLEN, D. J., FORSTER, A., PHAROAH, T. C. and KING, C. 2004. Geology of London. Memoir of the British Geological Survey, Sheet 256 (North London), 257 (Romford), 270 (South London) and 271 (Dartford) (England \& Wales). 
M A Woods

GALE, A. S. 1995. Cyclostratigraphy and correlation of the Cenomanian Stage in

Western Europe. In: HOUSE, M. R. \& GALE, A. S. (eds.) Orbital Forcing

Timescales and Cyclostratigraphy. Geological Society Special Publication, 85, 177197.

GALE, A. S. 1996. Turonian correlation and sequence stratigraphy of the Chalk in southern England. In: HESSELBO, S. P. \& PARKINSON, D. N. (eds) Sequence Stratigraphy in British Geology, Geological Society Special Publication, 103, 177 195.

GRAY, D. A. 1958. Electrical resistivity marker bands in the Lower and Middle Chalk of the London Basin. Bulletin of the Geological Survey of Great Britain, 15, 85-95.

GRAY, D. A. 1965. The stratigraphical significance of electrical resistivity marker bands in the Cretaceous strata of the Leatherhead (Fetcham Mill) Borehole, Surrey. Bulletin of the Geological Survey of Great Britain, 23, 65-115.

HOPSON, P. M., ALDISS, D. T. \& SMITH, A. 1996. Geology of the country around Hitchin. Memoir of the British Geological Survey, Sheet 221 (England \& Wales).

JARVIS, I. \& TOCHER, B. A. 1987. Field Meeting: the Cretaceous of SE Devon, 14 - 16th March, 1986. Proceedings of the Geologists' Association, 98, 51-66. 
M A Woods

JARVIS, I. \& WOODROOF, P. B. 1984. Stratigraphy of the Cenomanian and basal Turonian (Upper Cretaceous) between Branscombe and Seaton, S E Devon, England. Proceedings of the Geologists' Association, 95, 193-215.

JEFFERIES, R. P. S. 1963. The stratigraphy of the Actinocamax plenus Subzone (Turonian) in the Anglo-Paris Basin. Proceedings of the Geologists' Association, 74, $1-33$.

JONES, H. \& ROBINS, N. S. (eds). 1999. The Chalk Aquifer of the South Downs, National Groundwater Survey. British Geological Survey Hydrogeology Report Series.

MORTIMORE, R. N. 1986. Stratigraphy of the Upper Cretaceous White Chalk of Sussex. Proceedings of the Geologists' Association, 97, 97-139.

MORTIMORE, R. N. \& POMEROL, B. 1987. Correlation of the Upper Cretaceous White Chalk (Turonian to Campanian) in the Anglo-Paris Basin. Proceedings of the Geologists' Association. 98, 97-143.

MORTIMORE, R. N., WOOD, C. J. \& GALLOIS, R. W. 2001. British Upper Cretaceous Stratigraphy. Geological Conservation Review Series, No. 23, Joint Nature Conservation Committee, Peterborough. 
M A Woods

MURRAY, K. H. 1986. Correlation of electrical resistivity marker bands in the

Cenomanian and Turonian Chalk from the London Basin to east Yorkshire. Report of the British Geological Survey, 17, No. 8.

RAWSON, P. F., ALLEN, P. \& GALE, A. S. 2001. The Chalk Group - a revised lithostratigraphy. Geoscientist, 11, 21.

ROBINSON, N. D. 1986. Lithostratigraphy of the Chalk Group of the North Downs, southeast England. Proceedings of the Geologists' Association, 97, 141-170.

SCHÜRCH, M. \& BUCKLEY, D. K. 2002. Integrating geophysical and hydrochemical borehole log measurements to characterise the chalk aquifer, Berkshire, UK. Hydrogeology Journal, 10, 610-627.

WHITHAM, F. 1991. The stratigraphy of the Upper Cretaceous Ferriby, Welton and Burnham formations north of the Humber, north-east England. Proceedings of the Yorkshire Geological Society, 48, 227-255.

WHITHAM, F. 1993. The stratigraphy of the Upper Cretaceous Flamborough Chalk Formation north of the Humber, north-east England. Proceedings of the Yorkshire Geological Society, 49, 235-258.

WHITTAKER, A., HOLLIDAY, D. W. \& PENN, I. E. 1985. Geophysical logs in British stratigraphy. Special Publication of the Geological Society, 18, 74 pp. 
M A Woods

WILKINSON, I. P. 2003. Late Cretaceous foraminifera from Lower Venson Farm Borehole. British Geological Survey Internal Report, IR/03/143R.

WOOD, C. J. 1986. Appendix. In: MURRAY, K. H. Correlation of electrical resistivity marker bands in the Cenomanian and Turonian Chalk from the London Basin to east Yorkshire. Report of the British Geological Survey, 17, No. 8.

WOOD, C. J. 1988. The stratigraphy of the Chalk of Norwich. Bulletin of the Geological Society of Norfolk, 38, 3-120.

WOOD, C. J. 1996. Upper Cretaceous: Chalk Group. In: SUMBLER, M. G. (compiler). British Regional Geology: London and the Thames Valley (4th edition).. (London: HMSO for the British Geological Survey), 76-91.

WOOD C. J. \& SMITH, E. G. 1978. Lithostratigraphical classification of the Chalk in North Yorkshire, Humberside and Lincolnshire. Proceedings of the Yorkshire Geological Society, 42, 263-287.

WOODS, M. A. \& ALDISS, D. T. 2004. The stratigraphy of the Chalk Group of the Berkshire Downs. Proceedings of the Geologists' Association, 115, 249-265. 
M A Woods (top of figure)

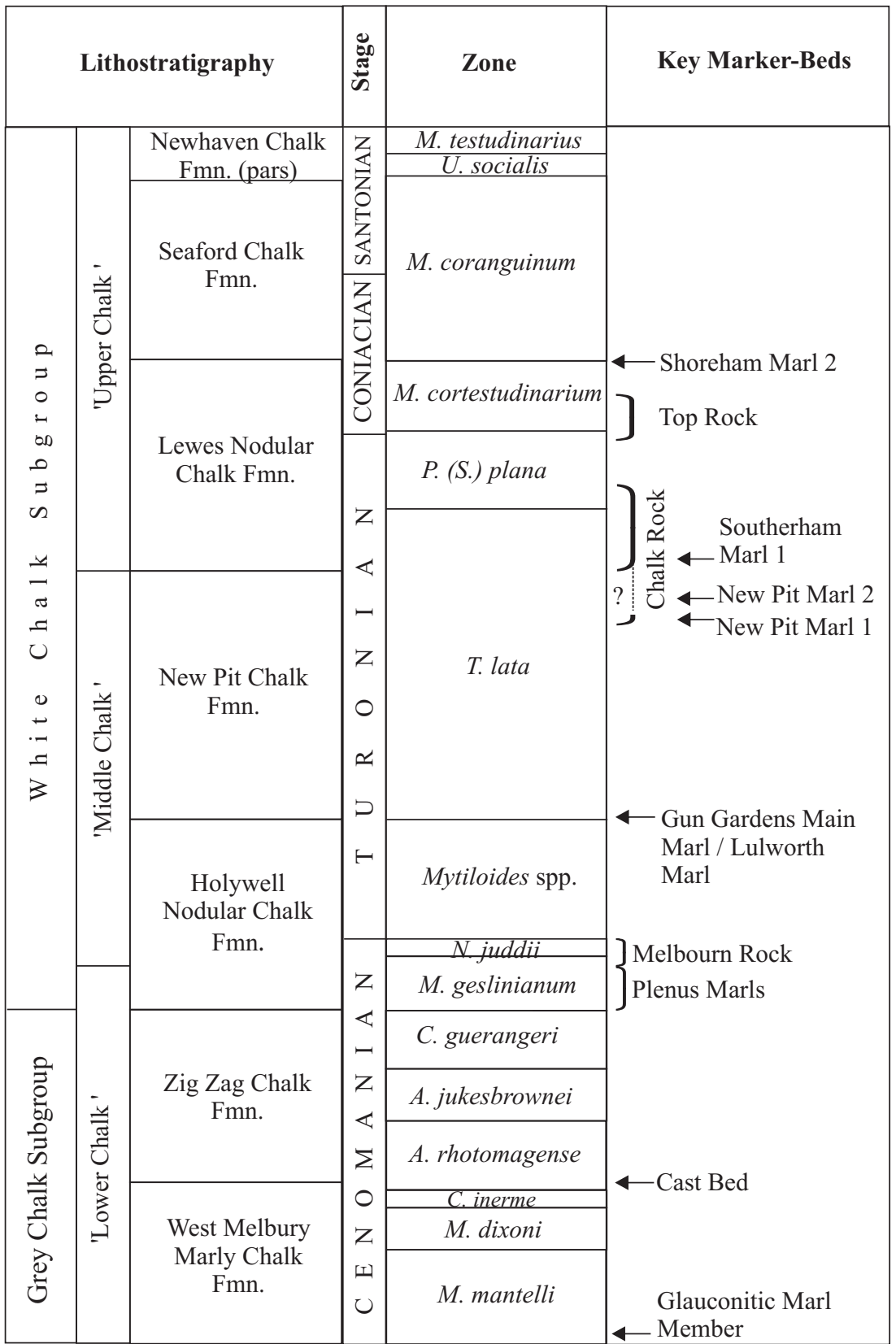

FIGURE 1 The stratigraphy of the Cenomanian to Santonian Chalk Group of south-east England (not to scale) 




FIGURE 2 The location of key cored boreholes and regional borehole geophysical studies in the Chalk Group of south-east England. 


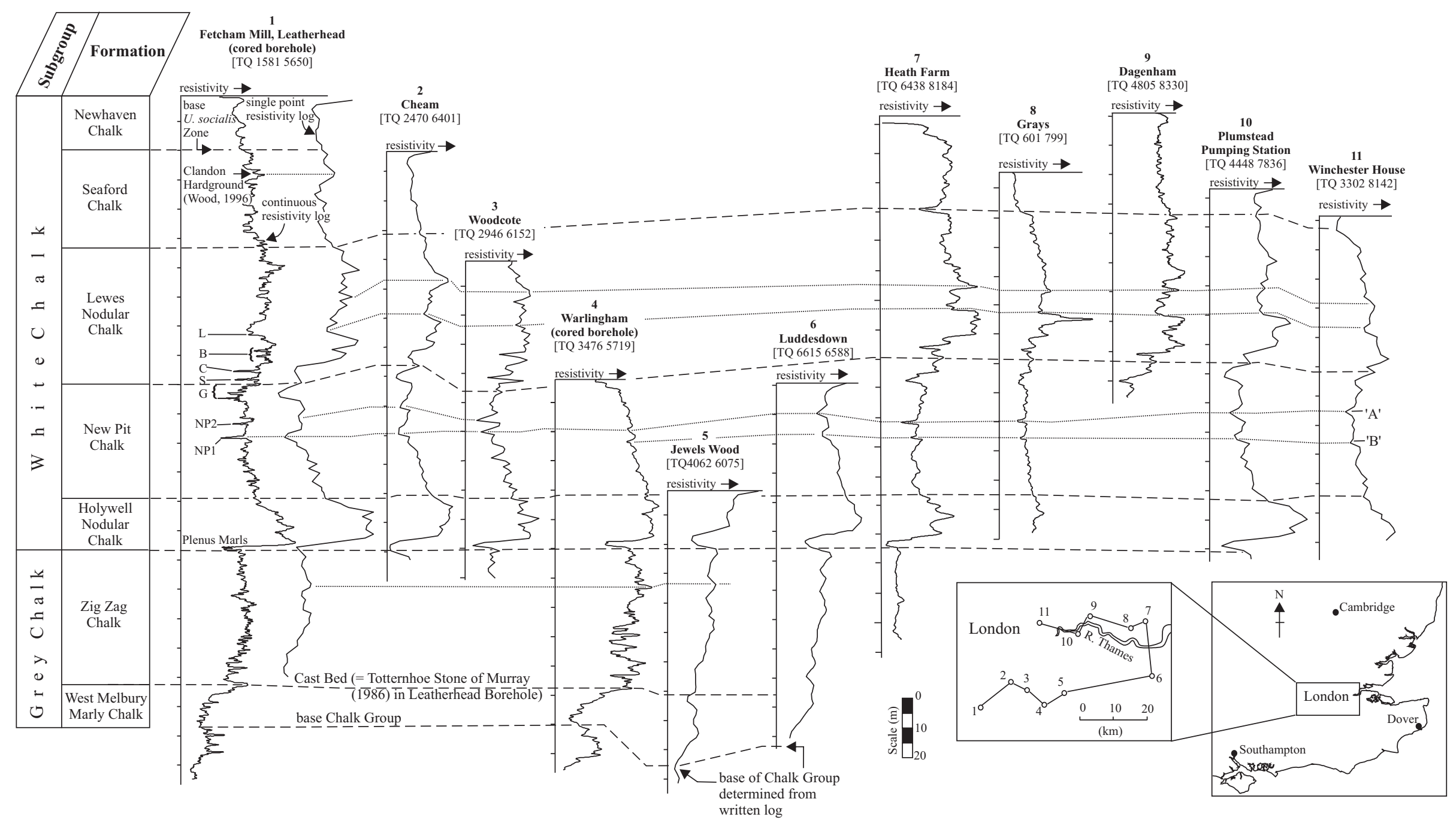

FIGURE 3 Lithostratigraphical interpretation and correlation of borehole geophysical

Marl seams identified by Wood (1986) in the Leatherhead Borehole: logs in the Chalk Group of the London district.

NP1 New Pit Marl 1

NP2 New Pit Marl 2

G Glynde Marl Complex

S Southerham Marl

$\begin{array}{ll}\text { C } & \text { Caburn Marl } \\ \text { B } & \text { Bridgewick Marls }\end{array}$

L Lewes Marl 




W $\quad$ i 1 l

B

S u r r e y

E

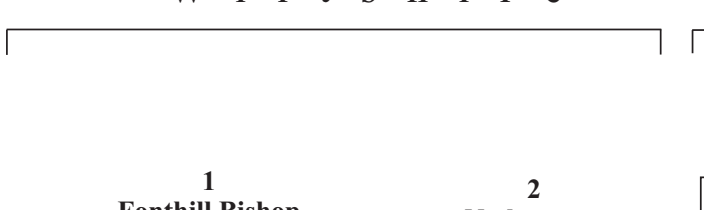

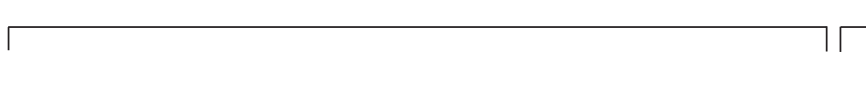

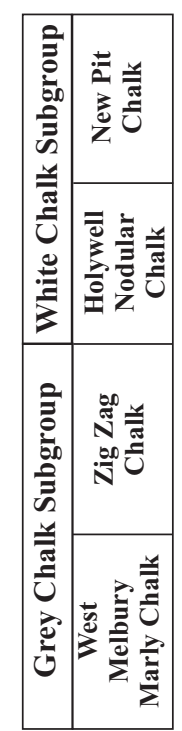

Fonthill Bishop

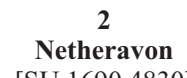

[ST 94091 34079]

[SU 1690 4830]

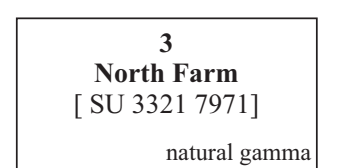

4

5
arracks OBH

6

6 ill, Leatherhead

(cored borehole)

[SU 3846 8017] [SU 4662 8156] [TQ 1581 5650]

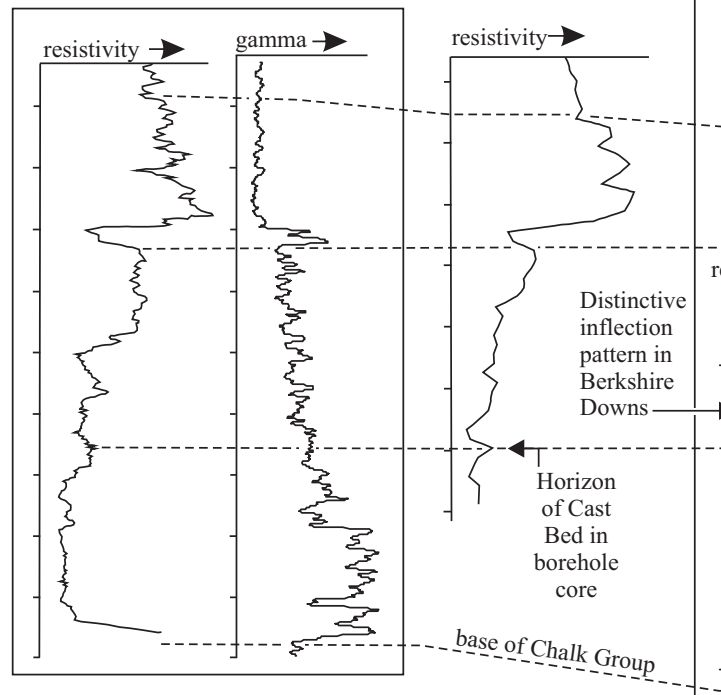

natural gamm

resistivity $\rightarrow$

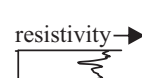

esistivity $\rightarrow$

Wor

(20)

Aycliff

(Dover No. 1)

[TR 2949 3958]


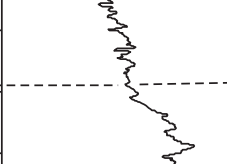
[TR 1836045330$]$
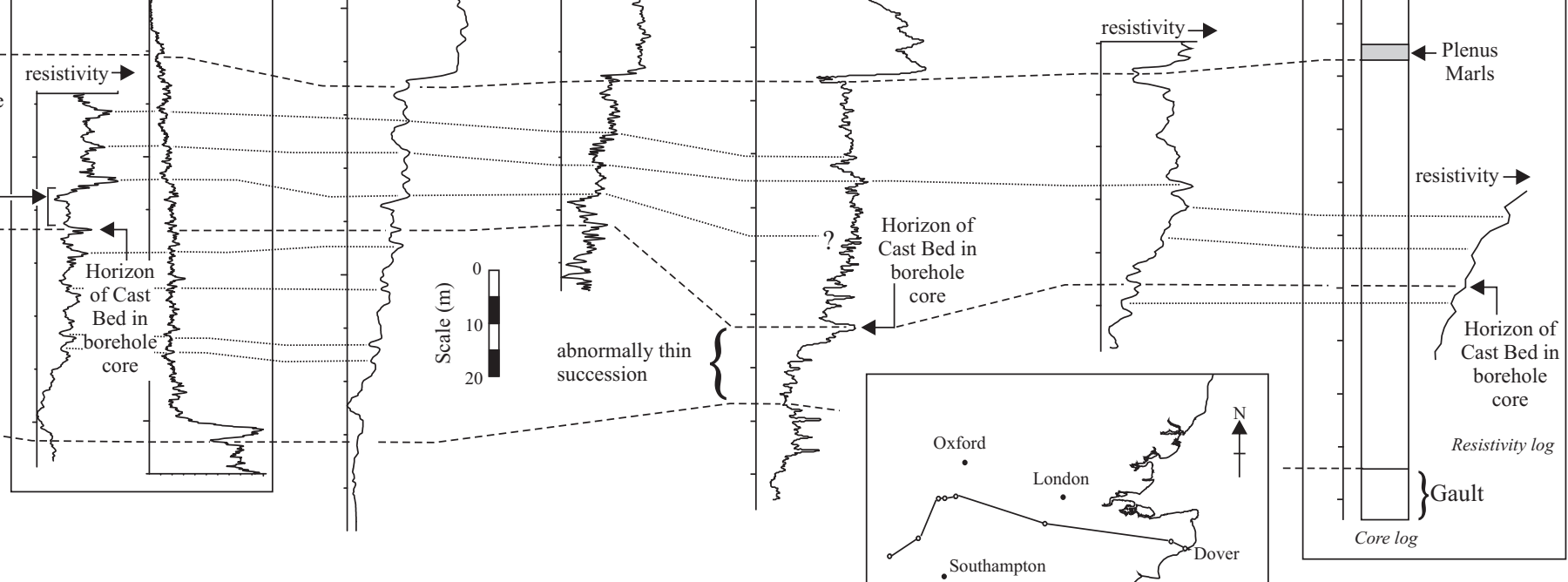

FIGURE 4 Lithostratigraphical interpretation and correlation of borehole geophysical logs in the Grey Chalk Subgroup and basal White Chalk Subgroup across southern England. 


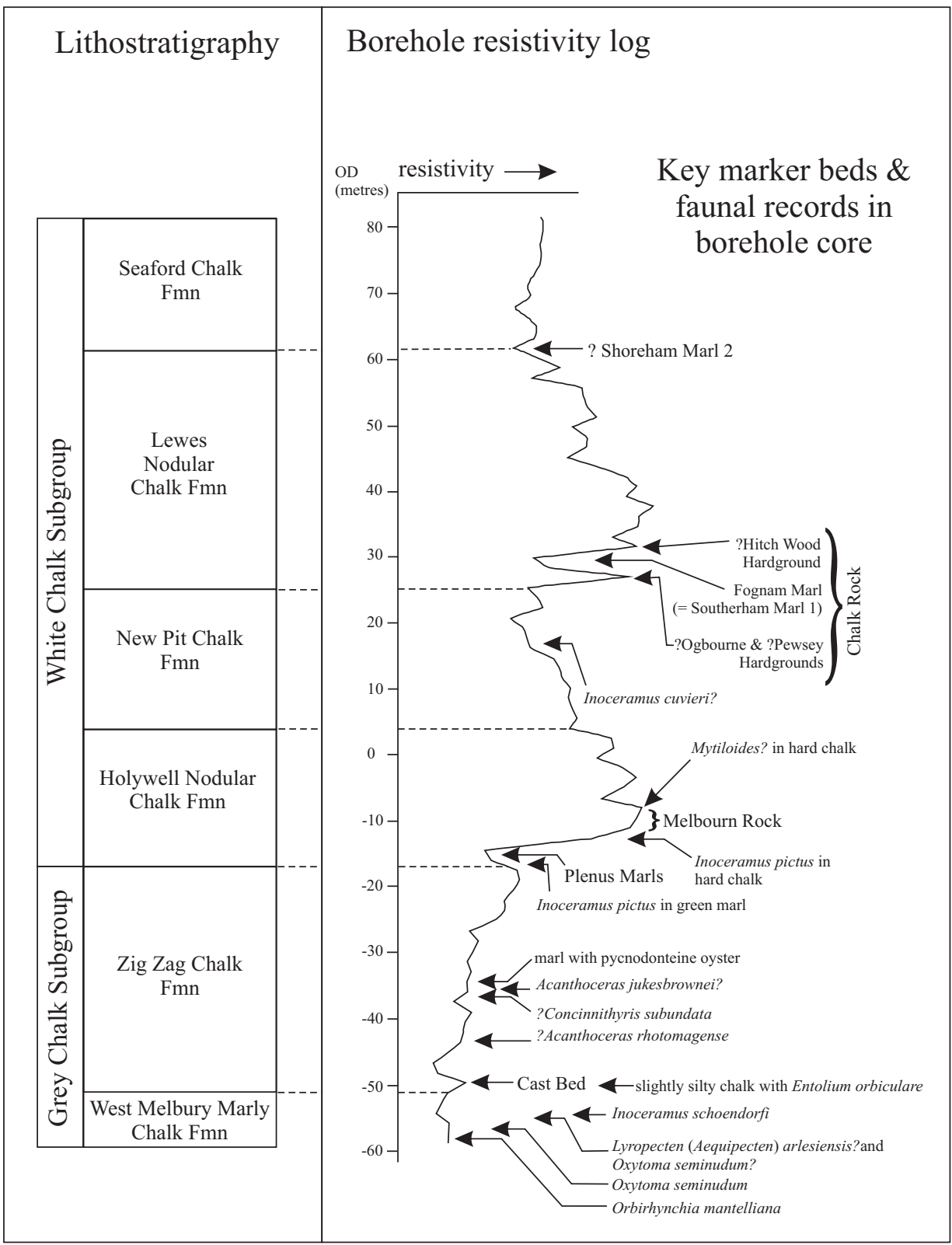

FIGURE 5 The lithostratigraphical interpretation of the resistivity $\log$ of the Netheravon Borehole with respect to markerbeds and key fossil occurrences in the borehole core. 
M A Woods (top of figure)

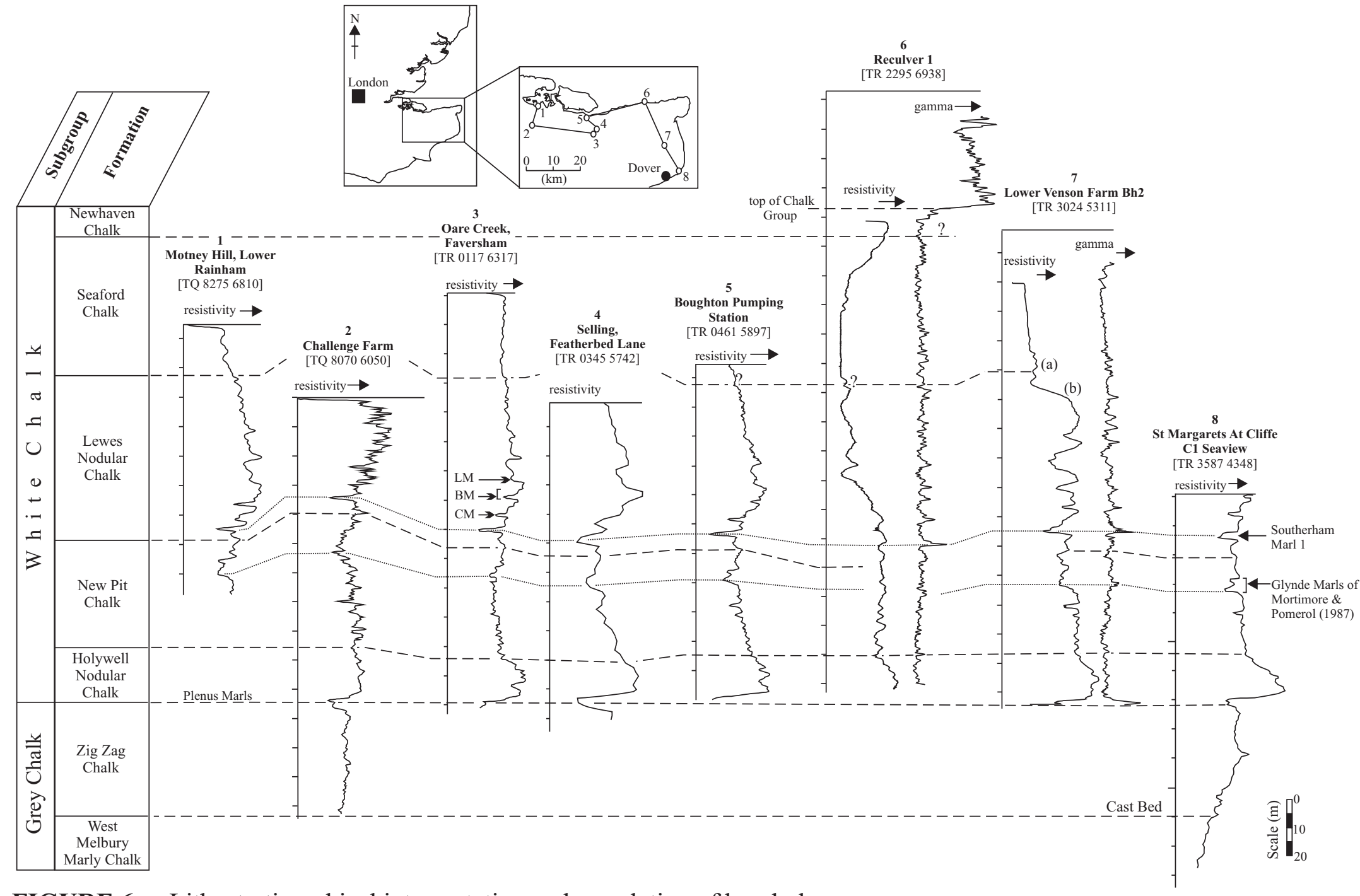

FIGURE 6 Lithostratigraphical interpretation and correlation of borehole geophysical logs in the Chalk Group of Kent.

(a): First up-hole macrofossil evidence of the M. coranguinum Zone

(b): First up-hole microfossil evidence of the M. coranguinum Zone (Wilkinson, 2003)

CM: Caburn Marl of Mortimore \& Pomerol (1987)

BM: Bridgewick Marls of Mortimore \& Pomerol (1987)

LM: Lewes Marl of Mortimore \& Pomerol (1987) 


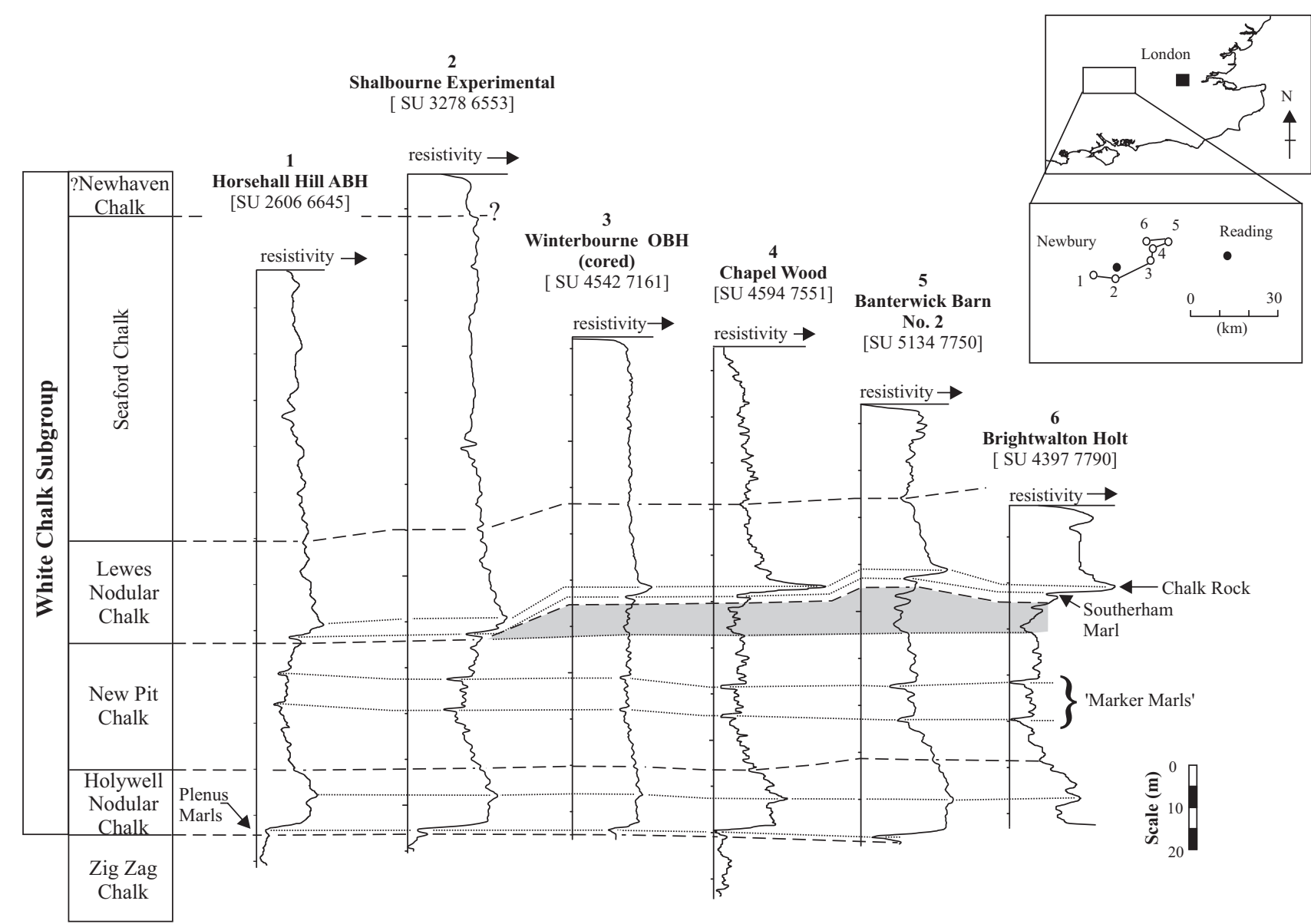

FIGURE 7 Lithostratigraphical interpretation and correlation of borehole geophysical logs in the Chalk Group of the Berkshire Downs.

Interval of New Pit Chalk showing lateral thickness changes 


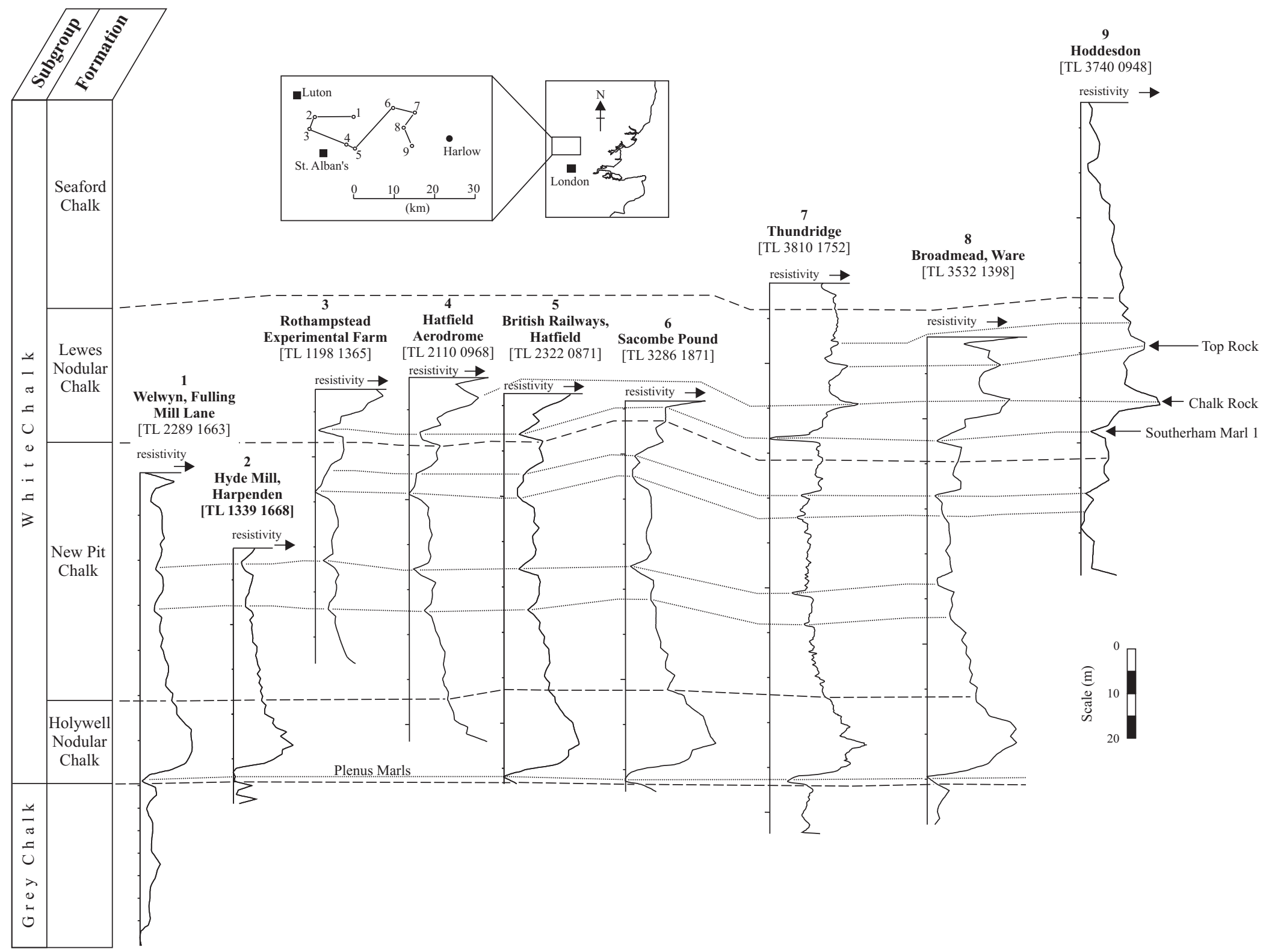

FIGURE 8 The lithostratigraphical interpretation and correlation of borehole geophysical logs in the Chalk Group of Hertfordshire. 